\title{
Celiac Immunogenic Potential of $\alpha$-Gliadin Epitope Variants from Triticum and Aegilops Species
}

\author{
Ángela Ruiz-Carnicer ${ }^{1}$, Isabel Comino ${ }^{1}$, Verónica Segura ${ }^{1}$ (D) Carmen V. Ozuna ${ }^{2}$, \\ María de Lourdes Moreno ${ }^{1}$, Miguel Ángel López-Casado ${ }^{3}$, María Isabel Torres ${ }^{4}$, \\ Francisco Barro ${ }^{2}$ and Carolina Sousa ${ }^{1, *}$ \\ 1 Departamento de Microbiología y Parasitología, Facultad de Farmacia, Universidad de Sevilla, 41012 Sevilla, \\ Spain; acarnicer@us.es (Á.R.-C.); icomino@us.es (I.C.); vsegura@us.es (V.S.); lmoreno@us.es (M.d.L.M.) \\ 2 Departamento de Mejora Genética Vegetal, Instituto de Agricultura Sostenible (IAS-CSIC), 14004 Córdoba, \\ Spain; carmen.ozuna@eez.csic.es (C.V.O.); fbarro@ias.csic.es (F.B.) \\ 3 Departamento de Gastronterología pediátrica, Hospital Virgen de las Nieves, 18014 Granada, Spain; \\ drlopezcasado@digestivointegral.es \\ 4 Departamento de Biología Experimental, Campus Universitario Las Lagunillas, 23071 Jaén, Spain; \\ mitorres@ujaen.es \\ * Correspondence: csoumar@us.es; Tel.: +34-954-556-452
}

Received: 28 December 2018; Accepted: 17 January 2019; Published: 22 January 2019

\begin{abstract}
The high global demand of wheat and its subsequent consumption arise from the physicochemical properties of bread dough and its contribution to the protein intake in the human diet. Gluten is the main structural complex of wheat proteins and subjects affected by celiac disease (CD) cannot tolerate gluten protein. Within gluten proteins, $\alpha$-gliadins constitute the most immunogenic fraction since they contain the main T-cell stimulating epitopes (DQ2.5-glia- $\alpha 1$, DQ2.5-glia- $\alpha 2$, and DQ2.5-glia- $\alpha 3$ ). In this work, the celiac immunotoxic potential of $\alpha$-gliadins was studied within Triticeae: diploid, tetraploid, and hexaploid species. The abundance and immunostimulatory capacity of $\mathrm{CD}$ canonical epitopes and variants (with one or two mismatches) in all $\alpha$-gliadin sequences were determined. The results showed that the canonical epitopes DQ2.5-glia- $\alpha 1$ and DQ2.5-glia- $\alpha 3$ were more frequent than DQ2.5-glia- $\alpha 2$. A higher abundance of canonical DQ2.5-glia- $\alpha 1$ epitope was found to be associated with genomes of the BBAADD, AA, and DD types; however, the abundance of DQ2.5-glia- $\alpha 3$ epitope variants was very high in BBAADD and BBAA wheat despite their low abundance in the canonical epitope. The most abundant substitution was that of proline to serine, which was disposed mainly on the three canonical DQ2.5 domains on position 8. Interestingly, our results demonstrated that the natural introduction of $\mathrm{Q}$ to $\mathrm{H}$ at any position eliminates the toxicity of the three T-cell epitopes in the $\alpha$-gliadins. The results provided a rational approach for the introduction of natural amino acid substitutions to eliminate the toxicity of three T-cell epitopes, while maintaining the technological properties of commercial wheats.
\end{abstract}

Keywords: celiac disease; $\alpha$-gliadin; 33-mer; DQ2.5-glia- $\alpha$ 1; DQ2.5-glia- $\alpha 2$; DQ2.5-glia- $\alpha 3$ epitopes; wheat species

\section{Introduction}

Wheat is one of the most widely cultivated cereals in the world and constitutes a major source of energy, protein, and fiber in the diet. Increasing global demand for wheat and its subsequent consumption, with an annual production of about 750 million tons, is due to its unique viscoelastic properties for its inclusion in food products and to industrialization and westernization [1-3]. The wheat group has evolved through allopolyploidization, that is, through hybridization between 
species from the genera Aegilops and Triticum followed by genome doubling [4]. Genetic studies have provided valuable information regarding which wild cereal species are the relatives of modern domesticated cereals, and which geographical wild plant produced the domesticated forms that are used in food production today [5]. The diploid wild wheat that was first domesticated is thought to have been Triticum monococcum $\left(A^{m} A^{m}\right)$, which is still growing in some parts of the world both for animal feed and human consumption. Wheats with more than one genome are known as polyploid wheats. The AA genome of the tetraploid wheats is closely similar to that of T. urartu, and the BB genome is related to Aegilops speltoides (BB). The wild tetraploid, formed after the hybridization, was designated as Triticum turgidum ssp. dicoccoides (wild emmer; BBAA), and the first domesticated tetraploid was T. turgidum ssp. dicoccum (cultivated emmer; BBAA), from which, the cultivated T. turgidum ssp. durum has evolved. The hexaploid wheat, Triticum aestivum ssp. aestivum (BBAADD), consists of three genomes designated A, B, and D. The A and B genomes of hexaploid wheats come from the $A$ and $B$ genomes of tetraploid wheat. The hexaploid wheats resulted from the hybridization of cultivated emmer and a wild grass species identified as Aegilops tauschii (DD), followed by polyploid formation which gave rise to a new species that has three genomes designated BBAADD [6,7]. The main wheat species grown throughout the world is the hexaploid T. aestivum, usually called "common" or "bread" wheat. In terms of total production, the next variety in importance is the tetraploid durum or macaroni wheat (T. turgidum L. subsp. durum Desf.). This is adapted to hot dry climates and is widely used for the production of pasta. Common wheat species account for nearly $94 \%$ of the total production, with durum wheat representing $5 \%$, and other wheat forms about $1 \%[6,8]$.

Although wheat has always been recognized as a fundamental food, this cereal cannot be tolerated by certain individuals since it is responsible for significant pathologies, called gluten-related disorders, such as celiac disease (CD), wheat allergy, non-celiac gluten sensitivity, gluten ataxia, and dermatitis herpetiformis [9]. CD is an immune-mediated systemic disorder elicited by the ingestion of gluten in genetically susceptible individuals. It affects around $1 \%$ of the global population and is based on a variable combination of intestinal and extra-intestinal signs and symptoms, celiac specific antibodies, HLA-DQ2/8 haplotypes, and enteropathy [9-11]. Gluten proteins are rich in proline and glutamine residues, which make them resistant to being fully digested in the gastrointestinal track. Partial digestion of gluten generates small peptides that provoke autoimmune disorders in celiac people. The most accepted model for explaining CD immunopathogenesis is the two-signal model [12] characterized by a first innate immune response followed by a secondary antigen-specific adaptive response. According to this model, certain peptides, such as the 19-mer gliadin peptide, trigger an innate immune response [13] mainly characterized by the production of interleukin 15 (IL-15) by epithelial cells. The result is the disruption of the epithelial barrier by increasing the permeability and inducing enterocyte apoptosis [14]. As a consequence, the immune-adaptive peptides, like the 33-mer, can now reach the lamina propria where they are deaminated by the tissue transglutaminase (tTG2). Such deamidation provides a negative charge to gliadin peptides and hence enhances their affinity to bind within the HLA-DQ2/8 bound, which is also the 'susceptibility gene' in CD, expressed on the surface of dendritic cells (DCs) [15-17]. DCs are therefore central in CD pathogenesis since they present a gluten antigen to T cells, [18] thereby driving progression of the pro-inflammatory antigen-specific adaptive immune response, which will turn into the symptomatology of the disease.

Gluten is a complex mixture of storage proteins of cereals such as wheat, rye, barley, oats, and their hybrid derivatives. Gluten proteins have been classified according to their solubility [19]. In wheat, these proteins are defined as gliadins (soluble in 60-70\% ethanol) and glutenins (only soluble under stronger conditions, i.e. acids, reducing agents and detergents, urea, etc.) [20]. According to their electrophoretic mobilities, gliadins are divided into three groups: $\alpha$ - and $\beta$-gliadins, $\gamma$-gliadins, and $\omega$-gliadins [19], while the glutenins are divided into the high molecular weight (HMW) and the low molecular weight (LMW) glutenin subunits (GSs) [21,22]. Among the gliadins, the $\alpha$-gliadins have the strongest immunogenicity [23], and four T-cell stimulatory epitopes have been identified as being responsible for eliciting the immunogenicity of $\alpha$-gliadin. Two of these are the major epitopes 
and they are present in the 33-mer peptide, which is the main contributor to the immunogenicity of the gluten [24] and contains six copies of these two overlapping T-cell epitopes: three copies of the DQ2.5-glia- $\alpha 1$ and three copies of the DQ2.5-glia- $\alpha 2$. The other two T-cell stimulatory epitopes are minor epitopes: DQ2.5-glia- $\alpha 3$ and DQ8-glia- $\alpha 1$ [24-27]. However, natural substitutions of these canonical epitopes could also contribute to the toxicity of wheat [28], and it could suggest that the total CD immunogenicity of gluten protein is a result of the canonical epitopes and their variants, some of which are more abundant than the canonical epitopes themselves. Gluten can have different immunogenic potential sequences whose proportions in each species are also variable. For this reason, it is important to study the amino acid substitutions in the variants of these epitopes; interestingly, these variants could increase, reduce, or suppress the CD response.

In earlier work, next-generation sequencing and Sanger sequencing of $\alpha$-gliadins from diploid and polyploid wheats provided six types of $\alpha$-gliadins with major differences in their frequencies. The canonical CD epitopes and their variants were identified in the different types of $\alpha$-gliadins [29]. In the present study, we used the sequence data with one or two mismatches and canonical epitopes obtained in Ozuna et al. [29], and we have built upon the previous research by exploring the abundance of different DQ2.5-glia- $\alpha 1$, DQ2.5-glia- $\alpha 2$, and DQ2.5-glia- $\alpha 3$ epitope variants per species in diploid and polyploid wheats. Moreover, the immunogenic potential of these epitope variants in wheat species was studied by testing their binding capacity to anti-33-mer monoclonal antibodies (moAbs) [30,31] and to induce T-cell proliferation. The anti-33-mer antibodies were able to detect the presence of gliadin 33-mer related epitopes in prolamins from wheat, barley, rye, and various oats varieties as well as in food samples and human samples to monitor gluten free diet (GFD) compliance and transgressions [32]. Our study showed that the canonical epitopes DQ2.5-glia- $\alpha 1$ and DQ2.5-glia- $\alpha 3$ were more frequent than DQ2.5-glia- $\alpha 2$. The most abundant natural modification was found in the DQ2.5-glia- $\alpha 3$ domain in all the sequences studied. However, this variant decreased its immunogenicity with respect to the canonical epitope. On the other hand, one of the most representative variants of DQ2.5-glia- $\alpha 2$ (40\%) showed an immunogenicity equivalent to the canonical epitope. Our results provide a rational approach for the introduction or selection of natural amino acid substitutions to eliminate the toxicity of three $\alpha$-gliadin T-cell epitopes, while keeping the technological properties of the commercial wheats.

\section{Materials and Methods}

\subsection{Catalogue and Abundance of CD Epitopes from Diploid, Tetraploid, and Hexaploid Wheat Varieties}

Canonical epitopes DQ2.5-glia- $\alpha 1$ (PF/YPQPQLPY), DQ2.5-glia- $\alpha 2$ (PQPQLPYPQ), and DQ2.5-glia- $\alpha 3$ (FRPQQPYPQ) and variants with one or two mismatches provided by Ozuna et al. [29] were obtained from diploid, tetraploid, and hexaploid wheats (Figure 1).

The frequency/abundance of each peptide in the sequences of the different wheats was studied in silico. The abundance of each epitope was calculated by multiplying the total number of epitopes found in a given gene by the frequency of that gene in the genome.

These canonical CD epitopes and their most representative variants with one or two mismatches were synthesized as deaminated and non-deaminated 9-mer peptides. The peptides were supplied by Biomedal S.L. (Seville, Spain). 


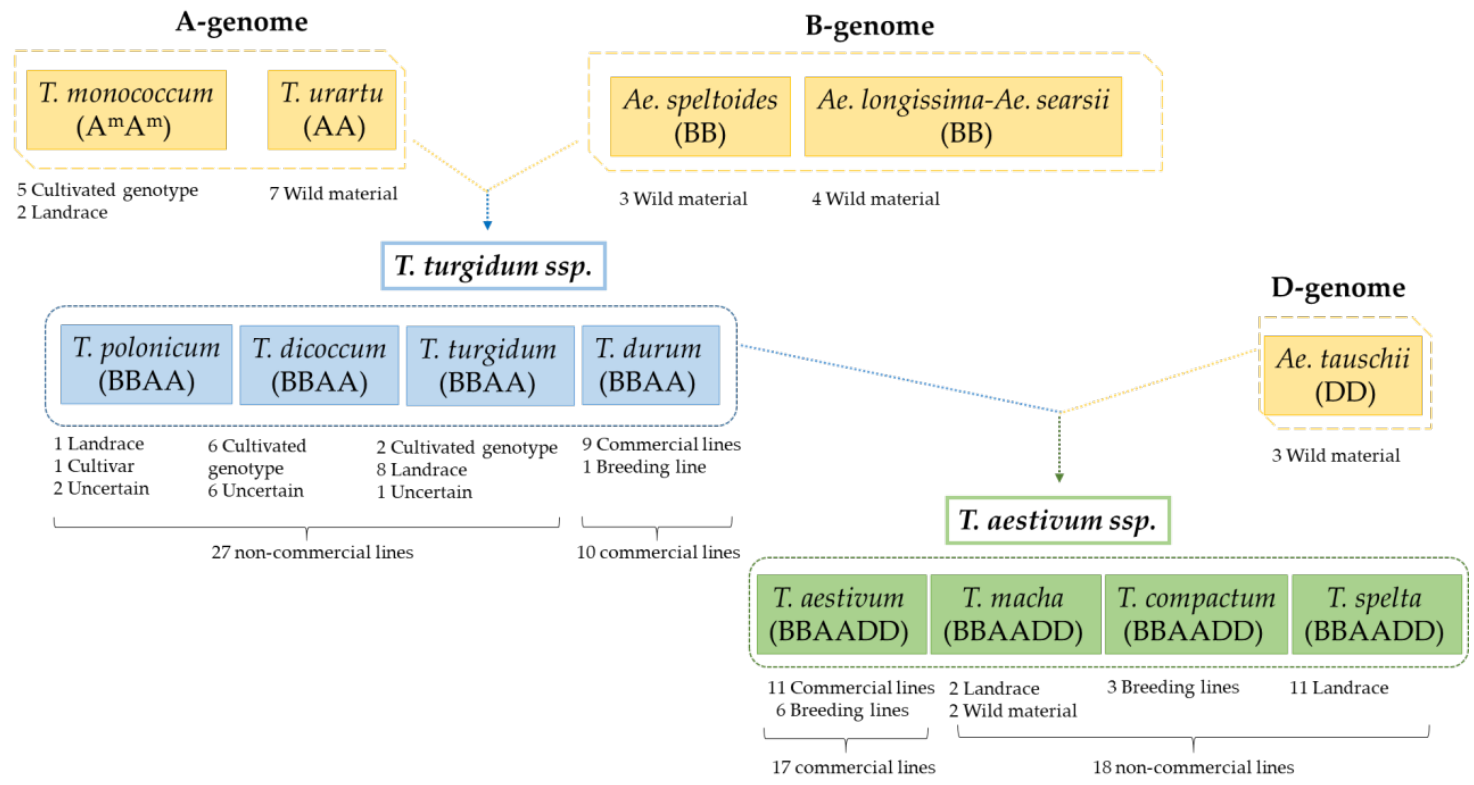

Figure 1. Schematic representation of 96 accessions from Triticum and Aegilops sp. showing their origin and breeding status. In total, there are thirty-five accessions of hexaploid wheats, thirty-seven accessions of tetraploid wheats, and twenty-four accessions of diploid wheats. AA, BB, and DD: diploids; BBAA: tetraploids; BBAADD: hexaploids (partially adapted from Ozuna and Barro) [3].

\subsection{Enzyme-Linked Immunosorbent Assay (ELISA)}

Maxisorp microtitre plates (Nunc, Roskilde, Denmark) were coated with gliadin solution (Sigma, St Louis, MO, USA) and incubated overnight at $4{ }^{\circ} \mathrm{C}$. The plates were washed with phosphate-buffered saline (PBS) containing 0.05\% Tween 20 and blocked with PBS-bovine serum albumin (BSA) 3\% for $1 \mathrm{~h}$ at room temperature (RT), and 33-mer peptide was used as standard. Serial dilutions of peptides were made, to each of which horseradish peroxidase (HRP)-conjugate with anti-33-mer antibody $(\mathrm{moAb})$ was added [32]. The samples were pre-incubated at RT for $1 \mathrm{~h}$ and then added to the wells. After $1 \mathrm{~h}$ of incubation at RT, the plates were washed and substrate solution (TMB, Sigma) was added. The reaction was stopped at $15 \mathrm{~min}$ with $1 \mathrm{M}$ sulfuric acid and the absorbance at $450 \mathrm{~nm}$ was measured (microplate reader UVM340; Asys Hitech GmbH, Eugendorf, Austria). Two separate assays were performed, each with two repetitions.

\subsection{Peripheral Blood Mononuclear Cells (PBMCs) and Cell Cultures}

Peripheral blood mononuclear cells from 18 child patients with active $\mathrm{CD}$ on a gluten-containing diet were isolated from $6 \mathrm{~mL}$ of heparinized blood by Histopaque gradient centrifugation and cultured at a density of $1 \times 10^{6}$ cells per milliliter in 96-multiwell culture plates in RPMI-1640 culture medium (Sigma-Aldrich) supplemented with 10\% fetal bovine serum (GIBCO-Invitrogen Ltd), 1\% penicillin-streptomycin, and $0.1 \%$ gentamicin (Sigma-Aldrich). After $48 \mathrm{~h}$, PBMCs were incubated with different peptides $(50 \mu \mathrm{g} / \mathrm{mL})$. After $48 \mathrm{~h}$ of stimulation, the free supernatants were collected and stored at $-80^{\circ} \mathrm{C}$ until the interferon gamma (IFN- $\gamma$ ) analyses were carried out.

\subsection{Cell Proliferation Analysis}

T-cell proliferation was determined after $48 \mathrm{~h}$ of incubation using the ELISA 5-bromo-2-deoxyuridine (BrdU) cell proliferation test (Millipore Chemicon, Temecula, California, USA). The stimulation index (SI) value was calculated by dividing the mean absorbance at $450 \mathrm{~nm}$ after stimulation by the mean absorbance of $\mathrm{T}$ cells exposed to the culture medium alone (negative control). 


\subsection{IFN- $\gamma$ Production}

Supernatants from the PBMC culture were collected after $48 \mathrm{~h}$ and stored at $80{ }^{\circ} \mathrm{C}$ for IFN- $\gamma$ determination using a commercial ELISA kit in accordance with the manufacturer's instructions (Thermo Scientific, Madrid, Spain). Standards were run on each plate. The sensitivity of the assay was $<2 \mathrm{pg} / \mathrm{mL}$.

\subsection{Statistical Analysis of T Cells and IFN- $\gamma$ Assays}

Each experiment was carried out in duplicate on separate days. The data is expressed as mean and SD. All statistical analyses were performed with the STATGRAPHICS Centurion XVI program. The analysis of variance (ANOVA), followed by the Tukey test for mean multiple comparison, was used. In this study, $p$ values lower than $0.05(p<0.05)$ were considered significant.

\section{Results and Discussion}

3.1. Relative Abundance of DQ2.5-Glia- $\alpha 1, D Q 2.5-G l i a-\alpha 2$, and DQ2.5-Glia- $\alpha 3$ Domains and Their Variants in Triticum and Aegilops Species

The complete repertoire of peptides involved in the pathogenesis of $C D$ remains a daunting task due to the great heterogeneity of gluten proteins [23,26]. Several studies have demonstrated that peptides derived from $\alpha$-gliadins induce the strongest T-cell responses in the vast majority of patients [23,33-35]. The $\alpha$-gliadins can have different sequences and their proportions in each species are also variable. In the present study, we have explored the abundance of different DQ2.5-glia- $\alpha 1$, DQ2.5-glia- $\alpha 2$, and DQ2.5-glia- $\alpha 3$ variants in 96 genotypes from diploid and polyploid wheats. Among these genotypes, 27 accessions were commercial lines and 69 were non-commercial lines (Figure 1).

The DQ2.5-glia- $\alpha$ epitopes are located in the 33-mer region of $\alpha$-gliadins (Figure 2a). Although seventy-eight variants were found for these three canonical epitopes across the Triticeae species [29], only the most representative variants (covered by $>80$ reads), encompassing one or two mismatches, were used for this study; of which 9 variants were from DQ2.5-glia- $\alpha 1,10$ from DQ2.5-glia- $\alpha 2$, and 14 from DQ2.5-glia- $\alpha 3$ (Figure $2 b$ ).

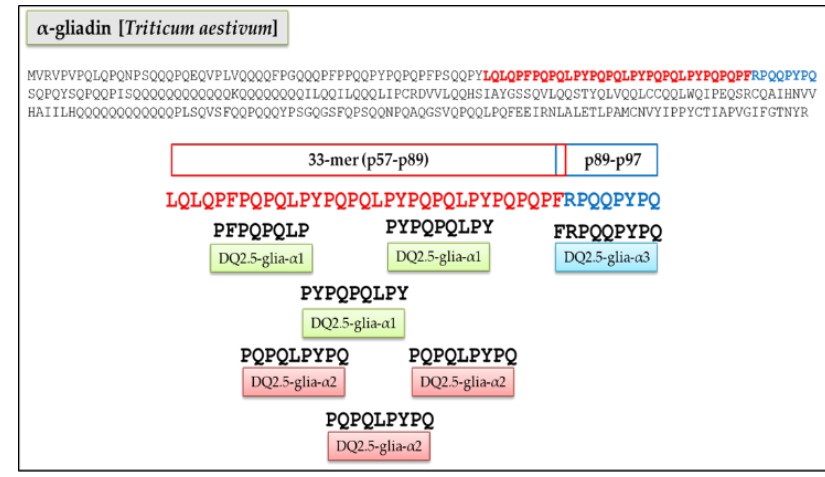

(a)

\begin{tabular}{|c|c|c|c|}
\hline Canonical epitope & DQ2.5-glia- $\alpha 1$ & DQ2.5-glia- $\alpha 2$ & DQ2.5-glia- $\alpha 3$ \\
\hline & $\underset{\mathrm{Y}}{\mathrm{PFPQPQLPY}}$ & PQPQLPYPQ & FRPQQPYPQ \\
\hline Mismatch & \multicolumn{3}{|c|}{ CD epitope variants } \\
\hline One mismatch & $\begin{array}{l}\text { PFPQLQLPY } \\
\text { PFLPQPLY } \\
\text { PFPQPQLSY } \\
\text { PFSQPQLPY } \\
\text { PYPPPHLY } \\
\text { PYPHPQLPY } \\
\text { PYPQPQLLY }\end{array}$ & $\begin{array}{l}\text { PQPQLPYSQ } \\
\text { PQPHLPYPQ } \\
\text { PQLQLPYPQ } \\
\text { PQPQLPYPH } \\
\text { PQPQLYYLQ } \\
\text { PQPQLLYPQ }\end{array}$ & $\begin{array}{l}\text { FPPQQPYPQ } \\
\text { FSPQQPYPQ } \\
\text { FRPQSYPQ } \\
\text { FLPQQPYPQ } \\
\text { FQPQQPYPQ } \\
\text { FRPQQPQPQ } \\
\text { FRPQPYLQ } \\
\text { FRQQQPYPQ }\end{array}$ \\
\hline Two mismatches & $\begin{array}{l}\text { PFPQLQQPY } \\
\text { PYPQPQLLPP }\end{array}$ & $\begin{array}{l}\text { PQPQPQYPQ } \\
\text { LQPQLPYSQ } \\
\text { SQPQLPYSQ } \\
\text { PQPQLPHSQ }\end{array}$ & $\begin{array}{l}\text { FLPQLPYPQ } \\
\text { FPPQQSYPQ } \\
\text { FPPQLPYPQ } \\
\text { FPSQQPYPQ } \\
\text { FPAQPYPPQ } \\
\text { FPPQQPYPH }\end{array}$ \\
\hline
\end{tabular}

(b)

Figure 2. Celiac disease (CD) epitopes and variants derived from $\alpha$-gliadin. (a) Location of canonical epitopes DQ-2.5-glia- $\alpha 1$, DQ-2.5-glia- $\alpha 2$, and DQ-2.5-glia- $\alpha 3$ into $\alpha$-gliadin protein. (b) Variants of the canonical CD epitopes with one or two mismatches selected with more than 80 reads found in Triticum and Aegilops ssp. The mismatches are indicated in red.

In view of the total abundance of the different canonical epitopes, DQ2.5-glia- $\alpha 1$ and DQ2.5-glia- $\alpha 3$ were more abundant than DQ2.5-glia- $\alpha 2(p<0.05$, Figure 3). There were no significant differences between the abundance of DQ2.5-glia- $\alpha 1$ and DQ2.5-glia- $\alpha 3$, however, we found higher variability of the DQ2.5-glia- $\alpha 1$ canonical epitope in hexaploid wheats, since its abundance fluctuated 
widely depending on the different hexaploid species, while it remained evenly distributed in the DQ2.5-glia- $\alpha 3$ canonical epitope ( $p=0.02$, Figure 3).

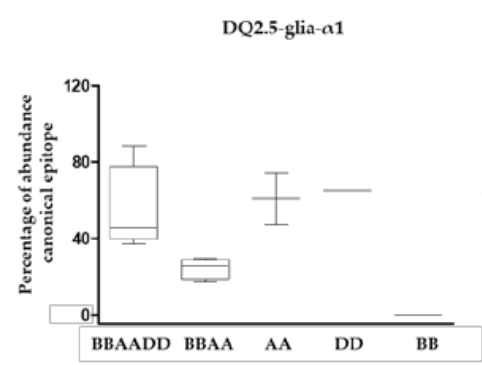

(a)

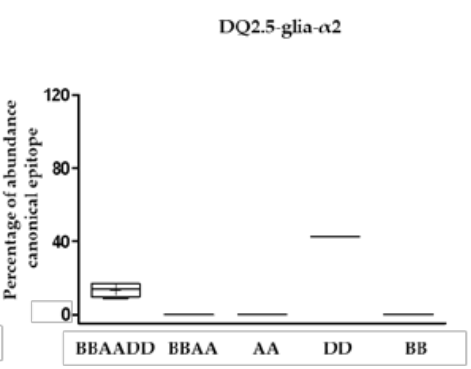

(b)

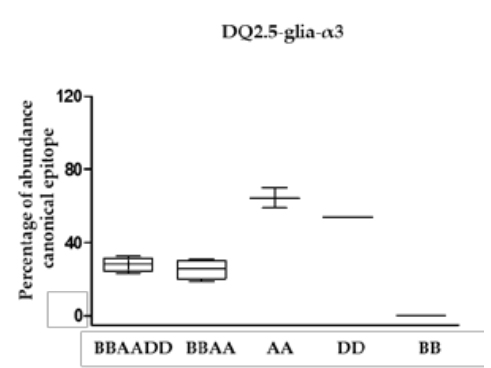

(c)

Figure 3. Abundance of CD canonical epitope and variants per wheat genome type. (a) Abundance of the canonical epitope DQ2.5-glia- $\alpha 1$ and variants, (b) abundance of the canonical DQ2.5-glia- $\alpha 2$ epitope and variants, and (c) abundance of the canonical DQ2.5-glia- $\alpha 3$ epitope and variants. BBAADD: hexaploid genome; BBAA: tetraploid genome; AA, DD, and BB: diploid genomes.

Figure 4 shows the abundance of CD canonical epitopes and variants per species. The percentage of DQ2.5-glia- $\alpha 1$ canonical epitope with respect to variants was $80 \%$. This epitope was present in all wheat genomes with the exception of BB diploids. The highest abundance was found in T. compactum, T. monococcum, and Ae. tauschii. The most abundant variant (range from $0.1 \%$ to $20 \%$ ) was $\mathrm{P}_{1} \mathrm{Y}_{2} \mathrm{P}_{3} \mathrm{Q}_{4} \mathrm{P}_{5} \mathrm{Q}_{6} \mathrm{~L}_{7} \mathbf{F}_{8} \mathbf{P}_{9}$ with two mismatches ( $\mathrm{P}$ to $\mathrm{F}$ at $\mathrm{p} 8$ and $\mathrm{Y}$ to $\mathrm{P}$ at $\mathrm{p} 9$ ). This variant was present in all wheat genomes with the exception of BB and DD diploids. The next most abundant variant was the substitution of $\mathrm{P}$ to $\mathrm{L}$ at p5, but this variant was present in only BBAA and BB genomes (Figure 5).

The percentage of DQ2.5-glia- $\alpha 2$ canonical epitope with respect to the different variants of this epitope was 14\%, and this epitope was only present in hexaploids BBAADD and DD diploids. This finding may indicate that this epitope came from Ae. tauschii, the donor of the $\mathrm{D}$ genome to bread wheat. The DQ2.5-glia- $\alpha 2$ variants $\mathrm{P}_{1} \mathrm{Q}_{2} \mathrm{P}_{3} \mathrm{Q}_{4} \mathrm{~L}_{5} \mathrm{P}_{6} \mathrm{Y}_{7} \underline{\mathrm{S}_{8}} \mathrm{Q}_{9}$ and $\mathrm{P}_{1} \mathrm{Q}_{2} \mathrm{P}_{3} \mathrm{Q}_{4} \mathrm{P}_{5} \mathrm{Q}_{6} \mathrm{Y}_{7} \mathrm{P}_{8} \mathrm{Q}_{9}$ were the most frequent (80\%). The highest abundance score (range from $46 \%$ to $74 \%$ ) of $\mathrm{P}_{1} \mathrm{Q}_{2} \mathrm{P}_{3} \mathrm{Q}_{4} \mathrm{~L}_{5} \mathrm{P}_{6} \mathrm{Y}_{7} \underline{\mathrm{S}_{8}} \mathrm{Q}_{9}$ ( $\mathrm{P}$ to $\mathrm{S}$ substitution at $\mathrm{p} 8$ ) occurred in AA diploids and was absent from DD and BB diploid genomes. In contrast, $\mathrm{P}_{1} \mathrm{Q}_{2} \mathrm{P}_{3} \mathrm{Q}_{4} \mathrm{P}_{5} \mathrm{Q}_{6} \mathrm{Y}_{7} \mathrm{P}_{8} \mathrm{Q}_{9}$ ( $\mathrm{L}$ to $\mathrm{P}$ at $\mathrm{p} 5$ and $\mathrm{P}$ to $\mathrm{Q}$ at $\mathrm{p} 6$ ), with two mismatches, presented high abundance in all genomes, with the exception of T. monococcum ( $\mathrm{A}^{\mathrm{m}} \mathrm{A}^{\mathrm{m}}$ diploid) (Figures 4 and 5).

Regarding the DQ2.5-glia- $\alpha 3$, the epitope variant $\mathrm{F}_{1} \underline{\mathrm{P}}_{2} \mathrm{P}_{3} \mathrm{Q}_{4} \mathrm{Q}_{5} \mathrm{P}_{6} \mathrm{Y}_{7} \mathrm{P}_{8} \mathrm{Q}_{9}$ (with $\mathrm{R}$ to $\mathrm{P}$ substitution at p2) was the most frequent, with an abundance greater than $75 \%$ across all species, except in Triticum polonicum (BBAA) and Triticum urartu $\left(\mathrm{A}^{\mathrm{u}} \mathrm{A}^{\mathrm{u}}\right)$, with abundances of $67.9 \%$ and $42.2 \%$, respectively. The second and third most frequent variants, $\mathrm{F}_{1} \underline{\mathrm{L}}_{2} \mathrm{P}_{3} \mathrm{Q}_{4} \underline{\mathrm{L}}_{5} \mathrm{P}_{6} \mathrm{Y}_{7} \mathrm{P}_{8} \mathrm{Q}_{9}$ ( $R$ to $\mathrm{L}$ at $\mathrm{p} 2$ and $\mathrm{Q}$ to $\mathrm{L}$ at p5) and $\mathrm{F}_{1} \underline{\mathrm{P}}_{2} \mathrm{P}_{3} \mathrm{Q}_{4} \mathrm{Q}_{5} \mathrm{~S}_{6} \mathrm{Y}_{7} \mathrm{P}_{8} \mathrm{Q}_{9}$ ( $\mathrm{R}$ to $\mathrm{P}$ at $\mathrm{p} 2$ and $\mathrm{P}$ to $\mathrm{S}$ at $\mathrm{p} 6$ ), had two mismatches and were absent in $\mathrm{AA}$ and DD diploid genomes, which could indicate that the BB genome is the origin of this variant in the polyploid varieties; in fact, the abundance of this epitope variant in the remaining genomes was very similar ( $\approx 20 \%$ ) (Figures 4 and 5).

The process of hybridization between Ae. tauschii and T. dicoccum provided the DD genome, and new gluten gene combinations, to hexaploid wheats, thereby considerably improving their bread baking properties compared to that of tetraploid wheats, particularly the HMW-glutenin subunits [36]. However, the DD genome also encodes for gliadins that have been reported as highly immunogenic, as the DD genome has the highest number of potential immunogenic $\alpha$-gliadin peptides [37], while those from the BB genome contribute the least [38,39]. We found that the three canonical epitopes are present in the DD genome, with a representation ranging from $43 \%$ to $65 \%$. In hexaploids (BBAADD), all canonical epitopes are also present, but in a smaller proportion $(<40 \%)$ than the DD genome. In contrast, in the AA genome, only DQ2.5-glia- $\alpha 1$ and DQ2.5-glia- $\alpha 3$ are present, and the BB genome is not represented by any of the canonical epitopes. 
(a)

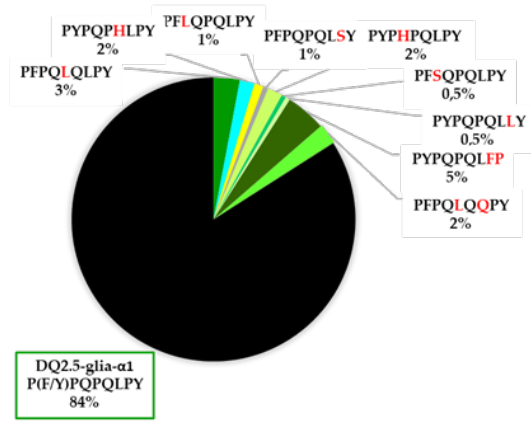

(c)

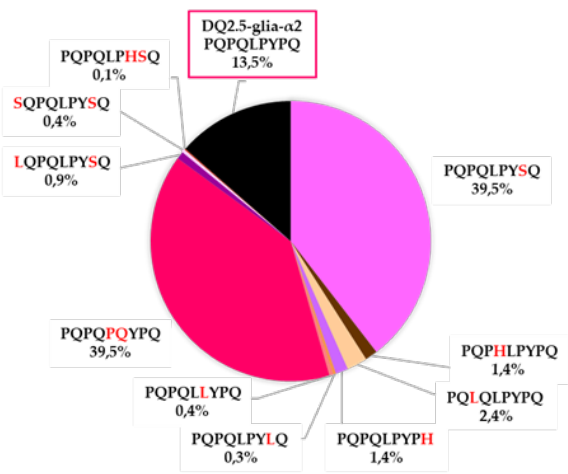

(e)

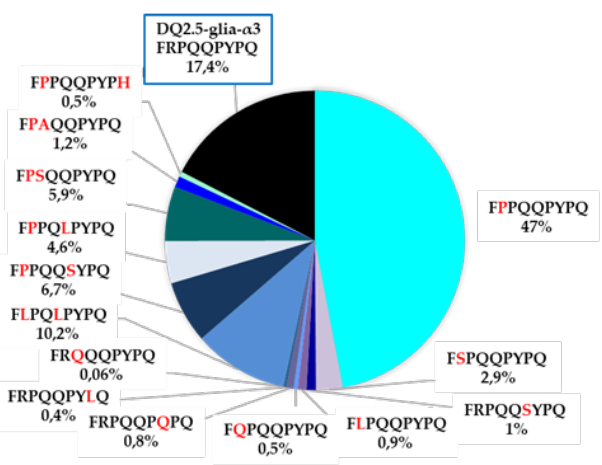

(b)

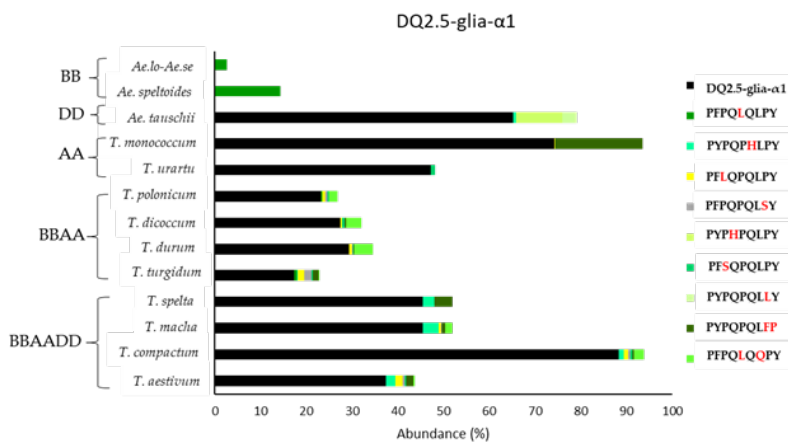

(d)

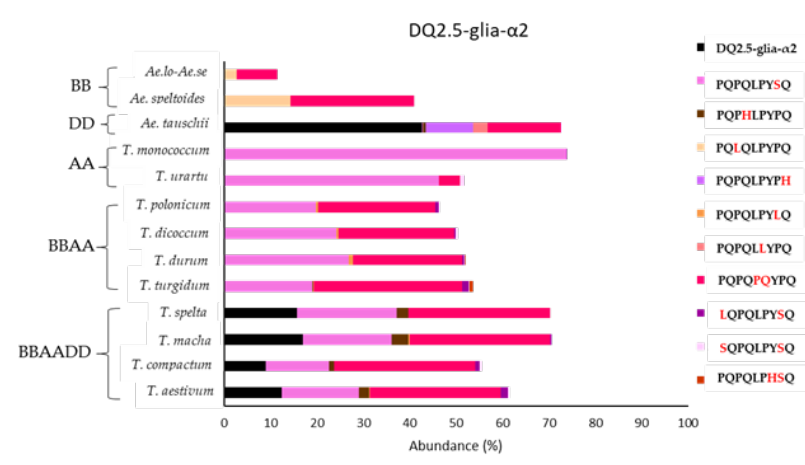

(f)

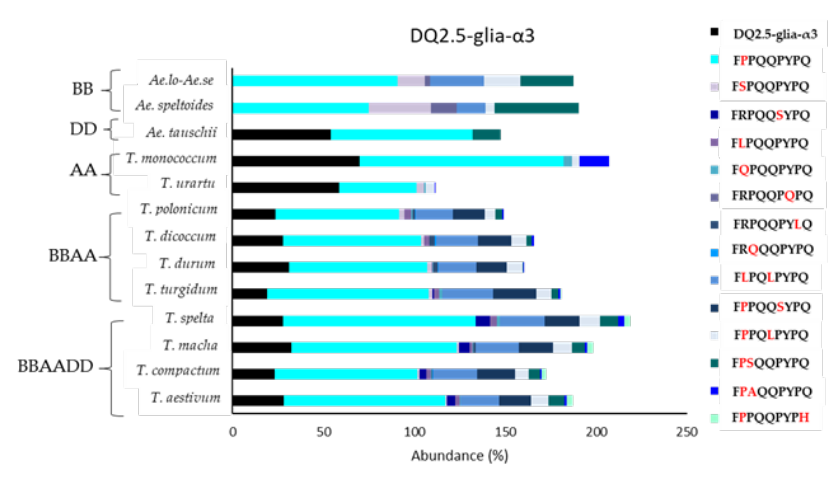

Figure 4. Abundance of CD canonical epitopes and variants per wheat species. (a) Abundance in the DQ2.5-glia- $\alpha 1$ epitope variants, (b) abundance in DQ2.5-glia- $\alpha 1$ epitope variants by species, (c) abundance in DQ2.5-glia- $\alpha 2$ epitope variants, (d) abundance in DQ2.5-glia- $\alpha 2$ epitope variants by species, (e) abundance in DQ2.5-glia- $\alpha 3$ epitope variants, and (f) abundance in DQ2.5-glia- $\alpha 2$ epitope variants by species. 
(a)

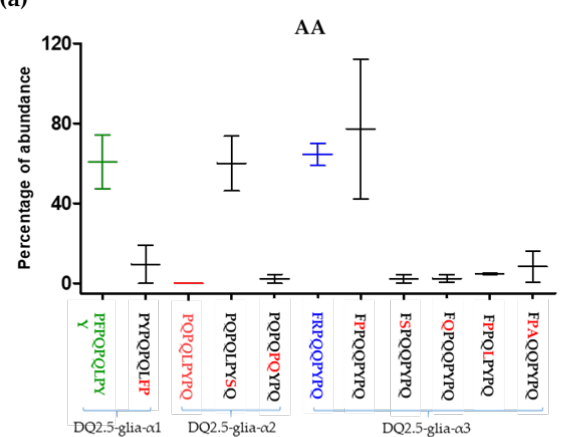

(b)

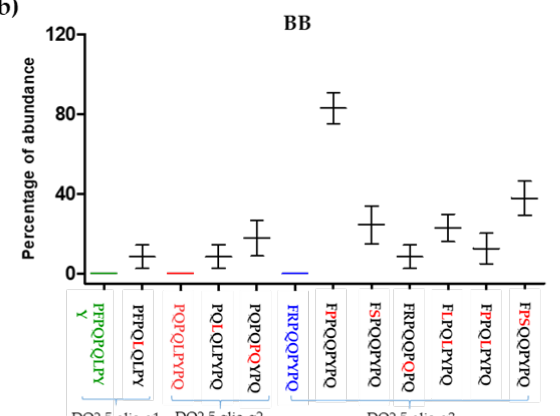

DQ2.5-gliara1 DQ2.5-glia-c2

(c)

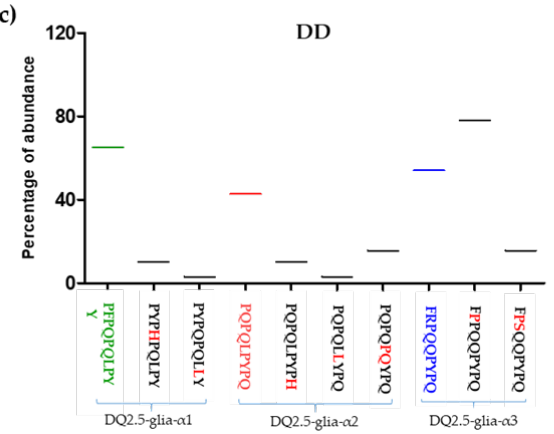

(d)

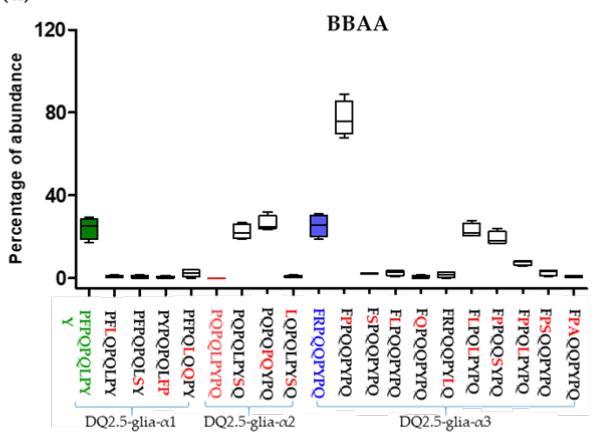

(e)

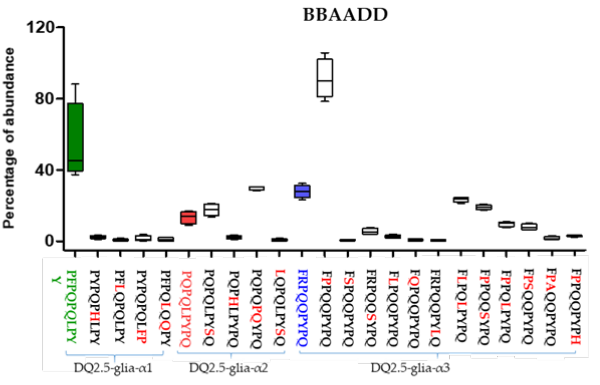

Figure 5. Abundance of epitope variants according to wheat genome type. The epitopes represented showed more than $1 \%$ of abundance in each gliadin domain. (a) AA genome, (b) BB genome, (c) DD genome, (d) BBAA genome, and (e) BBAADD genome. DQ2.5-glia- $\alpha 1$ epitope: green; DQ2.5-glia- $\alpha 2$ epitope: red; DQ2.5-glia- $\alpha 3$ epitope: blue.

\subsection{Anti-33-mer MoAb Binding Capacity and T-cell Stimulatory of DQ2.5- $\alpha$-Gliadin-Derived Peptides}

Several of the amino acid variants that we found in the $\alpha$-gliadin epitope sequences had never been described previously, while a number had been described but had never been tested for their immunogenic and stimulatory capacities. In order to determine which variants are capable of inducing a CD stimulatory response, the variants from DQ2.5-glia- $\alpha$ epitopes were synthesized as native and deaminated peptides and tested for their capacity to bind to anti-33-mer monoclonal antibodies (moAbs) and to induce T-cell proliferation, respectively (Figure 6). The latter was confirmed with gamma interferon assays (IFN- $\gamma$ ). The positioning of deamidated glutamine residues is strongly related to the positioning of proline residues, which is particularly strict in the case of DQ2.5 epitopes (but not DQ8 epitopes), as DQ2.5 only accepts proline at a certain position in the peptide binding groove $[26,40]$. The capacity of DQ2.5-glia- $\alpha$ epitopes to trigger proliferation of $\mathrm{T}$ cells was tested in deaminated peptides, deamidation of glutamine $(\mathrm{Q})$ at $\mathrm{p} 6$ in DQ2.5-glia- $\alpha 1$ domain, $\mathrm{p} 4$ in DQ2.5-glia- $\alpha 2$ domain, and $\mathrm{p} 4$ in DQ2.5-glia- $\alpha 3$ domain.

The DQ2.5-glia- $\alpha 1$ and DQ2.5-glia- $\alpha 2$ epitopes were regarded as major CD epitopes, as they are recognized by most of CD patients [41]. The anti-33-mer moAbs reacted strongly with the 
canonical DQ2.5-glia- $\alpha 1$ epitope $\mathrm{P}_{1}\{\mathrm{~F} / \mathrm{Y}\}_{2} \mathrm{P}_{3} \mathrm{Q}_{4} \mathrm{P}_{5} \mathrm{Q}_{6} \mathrm{~L}_{7} \mathrm{P}_{8} \mathrm{Y}_{9}$. In comparison with the canonical $\mathrm{CD}$ epitope, the variants $\mathrm{P}_{1} \mathrm{~F}_{2} \underline{\mathbf{L}}_{3} \mathrm{Q}_{4} \mathrm{P}_{5} \mathrm{Q}_{6} \mathrm{~L}_{7} \mathrm{P}_{8} \mathrm{Y}_{9}$ (proline (P) to leucine (L) substitution at $\mathrm{p} 3$ ) and $\mathrm{P}_{1} \mathrm{~F}_{2} \mathrm{~S}_{3} \mathrm{Q}_{4} \mathrm{P}_{5} \mathrm{Q}_{6} \mathrm{~L}_{7} \mathrm{P}_{8} \mathrm{Y}_{9}$ (P to serine (S) substitution at $\mathrm{p} 3$ ) showed a cross-reactivity (CR) of $37.7 \%$ and $55.4 \%$, respectively. With regard to studies of PBMCs in DQ2.5-glia- $\alpha 1$ variants, the single substitution $\mathrm{P}$ to $\mathrm{S}$ at $\mathrm{p} 3$ maintained similar stimulation capacity to that of the canonical epitope, although it was not abundant $(0.2 \%$ to $0.8 \%)$ in wheat species. Similarly, the variant with $\mathrm{P}$ to $\mathrm{L}$ substitution at $\mathrm{p} 3$ was very low in abundance $(0.1 \%$ to $1.6 \%$ ) and was found in all the polyploid species except for $T$. spelta, while in diploids it was only found in species with the AA genome. However, substitutions of $\mathrm{Q}$ to histidine $(\mathrm{H})$ at $\mathrm{p} 4$ and $\mathrm{p} 6$, respectively, abolished the stimulatory capacity of this epitope, probably because it provides a positive charge or via its influence in the deamidation at $\mathrm{p} 6$, as previously observed by Schumann et al. [42]. Moreover, $\mathrm{P}$ to $\mathrm{L}$ at $\mathrm{p} 8$, or two substitutions, also abolished the stimulatory capacity and showed no affinity for the moAbs (Figure 6a).

As indicated in Figure $6 \mathrm{~b}$, the variant $\mathrm{P}_{1} \mathrm{Q}_{2} \mathrm{P}_{3} \mathrm{Q}_{4} \mathrm{~L}_{5} \mathrm{P}_{6} \mathrm{Y}_{7} \underline{\mathrm{S}}_{8} \mathrm{Q}_{9}$ ( $\mathrm{P}$ to $\mathrm{S}$ substitution at $\mathrm{p} 8$ ) showed an anti-33-mer binding capacity and PBMC stimulation similar to that of the DQ2.5-glia- $\alpha 2$ canonical CD epitope. This common variant was found in polyploid and diploid species with AA genome, but was not found in $\mathrm{BB}$ and DD genomes. Those peptides with two mismatches, such as $\mathrm{P}_{1} \mathrm{Q}_{2} \mathrm{P}_{3} \mathrm{Q}_{4} \mathrm{P}_{5} \mathrm{Q}_{6} \mathrm{Y}_{7} \mathrm{P}_{8} \mathrm{Q}_{9}$ (substitutions $\mathrm{L}$ to $\mathrm{P}$ at $\mathrm{p} 5$ and $\mathrm{P}$ to $\mathrm{Q}$ at $\mathrm{p} 6$ ), $\mathrm{L}_{1} \mathrm{Q}_{2} \mathrm{P}_{3} \mathrm{Q}_{4} \mathrm{~L}_{5} \mathrm{P}_{6} \mathrm{Y}_{7} \mathrm{~S}_{8} \mathrm{Q}_{9}$ (substitutions $\mathrm{P}$ to $\mathrm{L}$ at $\mathrm{p} 1$ and $\mathrm{P}$ to $\mathrm{S}$ at $\mathrm{p} 8$ ), $\underline{\mathrm{S}}_{1} \mathrm{Q}_{2} \mathrm{P}_{3} \mathrm{Q}_{4} \mathrm{~L}_{5} \mathrm{P}_{6} \mathrm{Y}_{7} \mathrm{~S}_{8} \mathrm{Q}_{9}$ (substitutions $\mathrm{P}$ to $\mathrm{S}$ at $\mathrm{p} 1$ and $\mathrm{p} 8$ ), and $\mathrm{P}_{1} \mathrm{Q}_{2} \mathrm{P}_{3} \mathrm{Q}_{4} \mathrm{~L}_{5} \mathrm{P}_{6} \mathrm{H}_{7} \mathrm{~S}_{8} \mathrm{Q}_{9}$ (substitutions tyrosine ( $\mathrm{Y}$ ) to $\mathrm{H}$ at $\mathrm{p} 7$, and $\mathrm{P}$ to $\mathrm{S}$ at $\mathrm{p} 8$ ) showed a $\mathrm{CR}$ of $30-40 \%$ with respect to the canonical CD epitope and a stimulation index (SI) from 13 to 23 for PBMC stimulation. In contrast, the replacement of $\mathrm{P}$ to $\mathrm{L}$ at $\mathrm{p} 3$, p6, or $\mathrm{p} 8$ showed no reactivity with the moAbs. Among all of these variants, $\mathrm{P}_{1} \mathrm{Q}_{2} \mathrm{P}_{3} \mathrm{Q}_{4} \mathrm{~L}_{5} \mathrm{P}_{6} \mathrm{Y}_{7} \mathrm{~S}_{8} \mathrm{Q}_{9}$ and $\mathrm{P}_{1} \mathrm{Q}_{2} \mathrm{P}_{3} \mathrm{Q}_{4} \mathrm{P}_{5} \mathrm{Q}_{6} \mathrm{Y}_{7} \mathrm{P}_{8} \mathrm{Q}_{9}$ were the most frequent variants of the DQ2.5-glia- $\alpha 2$. The modification of $\mathrm{P}$ to $\mathrm{S}$ at $\mathrm{p} 8$ showed high stimulation with the moAbs and PBMCs, however, two mismatches of $\mathrm{L}$ to $\mathrm{P}$ at $\mathrm{p} 5$ and $\mathrm{P}$ to $\mathrm{Q}$ at $\mathrm{p} 6$ in the same sequence caused a threefold decrease in the immunogenicity of the DQ2.5-glia- $\alpha 2$ canonical epitope. This change is abundant in the BBAA genome, especially in the T. turgidum species.

Proliferation assays for PBMC with the canonical DQ2.5-glia- $\alpha 3$ epitope $F_{1} R_{2} P_{3} E_{4} Q_{5} P_{6} Y_{7} P_{8} Q_{9}$ were tested with $\mathrm{E}$ on $\mathrm{p} 4$ by $\mathrm{tTG}$-deamidation of the original $\mathrm{Q}$. Several peptides released an increased stimulatory effect on $T$ cells, such as the DQ2.5-glia- $\alpha 3$ variant $F_{1} \underline{L}_{2} \mathrm{P}_{3} \mathrm{Q}_{4} \underline{\mathbf{L}}_{5} \mathrm{P}_{6} \mathrm{Y}_{7} \mathrm{P}_{8} \mathrm{Q}_{9}$ with two mismatches. However, other variants for this epitope, with several amino acid substitutions, had no stimulatory effect on T cells, including $P$ to $S$ substitution at $\mathrm{p} 6, \mathrm{Y}$ to $\mathrm{Q}$ at $\mathrm{p} 7, \mathrm{P}$ to $\mathrm{Q}$ at $\mathrm{p} 3$, and two substitutions of arginine (R) to $\mathrm{P}$ at $\mathrm{p} 2$ and $\mathrm{Q}$ to $\mathrm{H}$ at $\mathrm{p} 9$ and $\mathrm{R}$ to $\mathrm{P}$ at $\mathrm{p} 2$ and $\mathrm{P}$ to $\mathrm{A}$ at $\mathrm{p} 3$ (Figure $6 \mathrm{c}$ ). The replacement of $R$ to $L$ at $p 2$ and $Q$ to $L$ at $p 5$ in the variant $F_{1} \underline{L}_{2} P_{3} Q_{4} L_{5} P_{6} Y_{7} P_{8} Q_{9}$ gave it greater stimulation capacity, given that this variant was highly abundant for the DQ2.5-glia- $\alpha 3$ epitope, it was found in all the polyploid species and in the BB diploid genome. However, the non-abundant variant $\mathrm{F}_{1} \mathbf{P}_{2} \mathrm{P}_{3} \mathrm{Q}_{4} \underline{\mathbf{L}}_{5} \mathrm{P}_{6} \mathrm{Y}_{7} \mathrm{P}_{8} \mathrm{Q}_{9}$ with the change of $\mathrm{R}$ to $\mathrm{P}$ at $\mathrm{p} 2$ and $\mathrm{Q}$ to $\mathrm{L}$ at $\mathrm{p} 5$ increased both the binding of the moAbs and stimulation with $\mathrm{T}$ cells. The variant $\mathrm{F}_{1} \mathrm{R}_{2} \mathrm{P}_{3} \mathrm{Q}_{4} \mathrm{~L}_{5} \mathrm{P}_{6} \mathrm{Y}_{7} \mathrm{~L}_{8} \mathrm{Q}_{9}$ with one mismatch (P to $\mathrm{L}$ at p8) showed T-cell stimulatory capacity and moAb binding, but was low in abundance ( $0.6 \%$ to $2.5 \%$ ). Nevertheless, one of the most abundant variants, $\mathrm{F}_{1}{\underline{S_{2}}}_{2} \mathrm{P}_{3} \mathrm{Q}_{4} \mathrm{Q}_{5} \mathrm{P}_{6} \mathrm{Y}_{7} \mathrm{P}_{8} \mathrm{Q}_{9}$, showed no T-cell stimulatory capacity and binding of the moAb and was found in the BB diploid genome.

According to the model of HLA-DQ2, the key amino acid residues for DQ2 binding lie at positions 1,7 , and 9 , with preferential residues at positions 4 and $6[43,44]$. On the other hand, Elli et al. [45] found that substitutions at positions $2,3,5$, and 8 also profoundly affected T-cell stimulation, indicating that these residues may all interact with the T-cell receptor (TCR). Our findings showed that the change at position 2 affected T-cell stimulation in the domain DQ2.5-glia- $\alpha 1$, at p8 in the DQ2.5-glia- $\alpha 2$ domain. In addition, the changes at positions 2,5 , and 8 in the DQ2.5-glia- $\alpha 3$ domain profoundly affected T-cell stimulation. Our results now provide new insights into an alternative approach, since we have showed that, by introducing specific amino acid substitutions, such as $\mathrm{Q}$ to $\mathrm{H}$, at any position, the toxicity of the three T-cell $\alpha$-gliadin epitopes could be eliminated. As such, the high level of variation influencing the immunogenicity of the major $\mathrm{CD}$ epitopes may offer possibilities to generate 
new wheat lines with reduced CD-immunogenicity, which may be potentially used as starting points for the breeding of safe wheats.
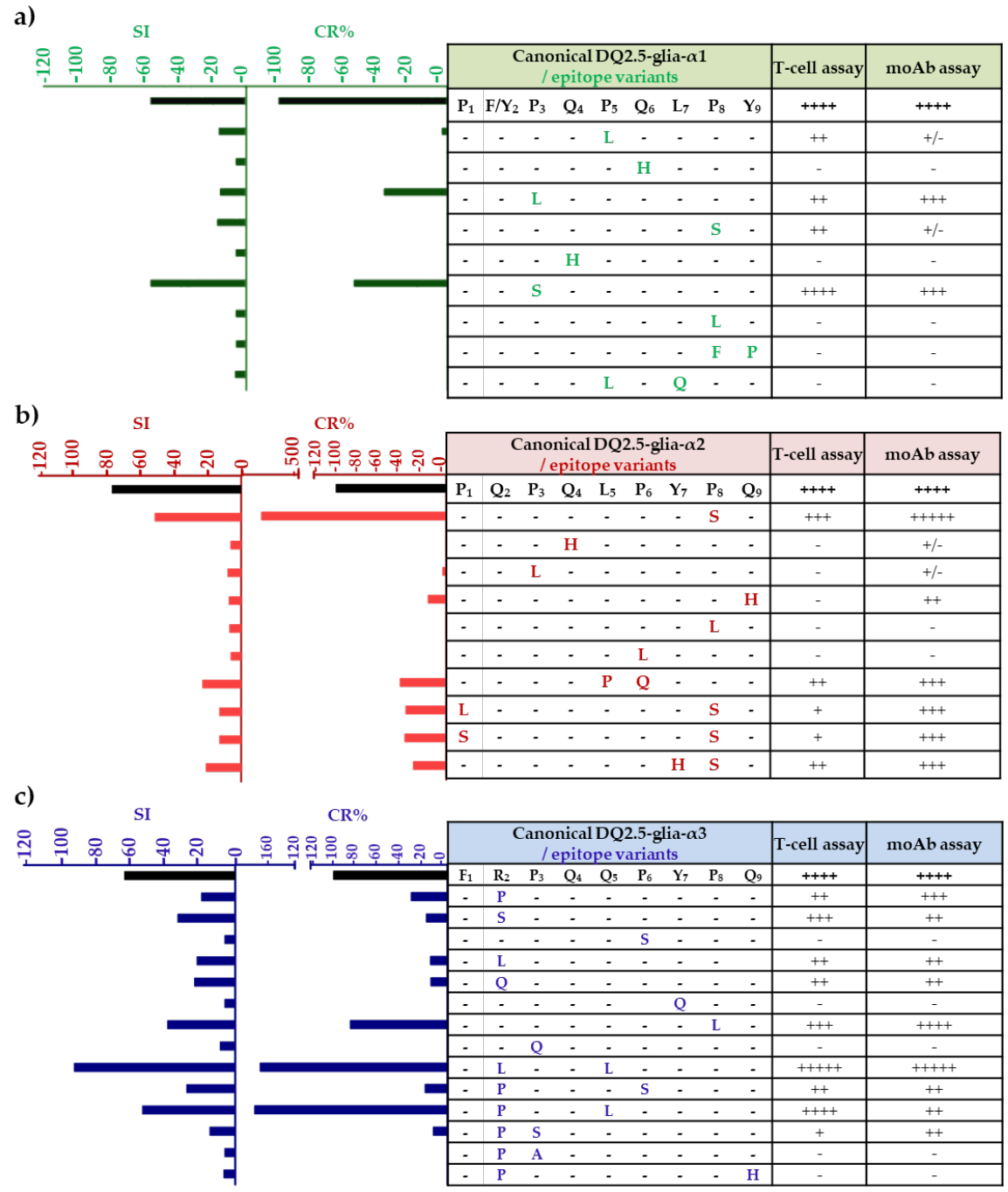

Figure 6. T-cell proliferation and anti-33-mer binding capacity of DQ2.5-glia- $\alpha 1$, DQ2.5-glia- $\alpha 2$, and DQ2.5-glia- $\alpha 3$ epitope variants and canonical epitope. (a) DQ-2.5-glia- $\alpha 1$ epitope and variants, (b) DQ-2.5-glia- $\alpha 2$ epitope and variants, and (c) DQ-2.5-glia- $\alpha 3$ epitope and variants. Variants and the canonical epitope were synthesized as deaminated 9-mer peptides to peripheral blood mononuclear cell (PBMC) assay. Proliferative responses of T cells were defined as a stimulation index (SI), which means the specific proliferation of a sample divided by the background proliferation ([PBMC + peptide]/[PBMC]). Glutamate residues (E) that would be formed by TG2-mediated deamination, which are important for recognition by $\mathrm{T}$ cells, are shown in italics. For the T-cell assay, the responses are represented relative to the maximum response given by the $\mathrm{CD}$ canonical epitope indicated by ++++ . Therefore, - corresponds with 15\%; + corresponds with 15-25\%; ++ corresponds with $25-50 \%$; +++ corresponds with $50-75 \%$; ++++ corresponds with $75-100 \%$; and +++++ corresponds with $>100 \%$. For the monoclonal antibody $(\mathrm{moAb})$ assay, the amount of antigen detected is represented relative to the maximum amount $(\mathrm{mol} / \mathrm{L})$ detected in a given assay by the $\mathrm{CD}$ canonical epitope indicated by ++++ . Therefore, - corresponds with $0 \% ;+/$ - corresponds with $<5 \%$; + corresponds with 5-10\%; ++ corresponds with 10-30\%; +++ corresponds to $30-60 \%$; ++++ corresponds to $60-100 \%$; and +++++ corresponds to $>100 \%$. CR; cross-reactivity, was calculated as follows: (IC50 of the antigen for which the moAb was raised/IC50 of each antigen assayed) $\times 100$. The IC50 is defined as the concentration of the line that reduces the peak absorbance by $50 \%$ in the assay. Each of the letters represents the amino acid substitution of the variants. 


\section{Conclusions}

The results presented here about CD DQ2.5 epitopes provide the basis for the introduction and/or selection of natural amino acid substitutions to eliminate the toxicity of the $\alpha$-gliadin T-cell epitopes. Our findings show that the most abundant epitope in the DQ2.5-glia- $\alpha 1$ domain is the $C D$ canonical epitope. Considering the DQ2.5-glia- $\alpha 2$ domain, the variants $\mathrm{P}_{1} \mathrm{Q}_{2} \mathrm{P}_{3} \mathrm{Q}_{4} \mathrm{~L}_{5} \mathrm{P}_{6} \mathrm{Y}_{7} \mathrm{~S}_{8} \mathrm{Q}_{9}$ and $\mathrm{P}_{1} \mathrm{Q}_{2} \mathrm{P}_{3} \mathrm{Q}_{4} \mathrm{P}_{5} \mathbf{Q}_{6} \mathrm{Y}_{7} \mathrm{P}_{8} \mathrm{Q}_{9}$ are the most abundant in this domain, while $\mathrm{F}_{1} \mathrm{P}_{2} \mathrm{P}_{3} \mathrm{Q}_{4} \mathrm{Q}_{5} \mathrm{P}_{6} \mathrm{Y}_{7} \mathrm{P}_{8} \mathrm{Q}_{9}$ is the most abundant in the DQ2.5-glia- $\alpha 3$ domain. Moreover, the $\mathrm{F}_{1} \mathrm{P}_{2} \mathrm{P}_{3} \mathrm{Q}_{4} \mathrm{Q}_{5} \mathrm{P}_{6} \mathrm{Y}_{7} \mathrm{P}_{8} \mathrm{Q}_{9}$ variant was also the most frequent of all the sequences studied. Our data indicate that the changes of $\mathrm{P}$ to $\mathrm{S}$ and $\mathrm{R}$ to $\mathrm{P}$ may be the most representative changes and the natural introduction of $\mathrm{Q}$ to $\mathrm{H}$ at any position eliminates the toxicity of the three T-cell epitopes. These results may offer possibilities to generate wheat varieties with a reduced CD-immunogenicity. Such varieties would help to reduce the presence of immunogenic CD epitopes in wheat flour and, while not safe for consumption by patients, might help to prevent the onset of $\mathrm{CD}$ in people that carry genetic risk factors. Overall, the more the scientific community knows about immunogenicity of the gliadins, the closer an alternative therapy besides GFDwill be achieved.

Author Contributions: Conceptualization, Á.R.-C., F.B., and C.S.; Data curation, Á.R.-C., C.V.O., and M.I.T.; Formal analysis, Á.R.-C., C.V.O., and M.I.T.; Investigation, Á.R.-C., I.C., V.S., M.d.L.M., C.V.O., M.Á.L.-C., M.I.T., F.B., and C.S.; Methodology, Á.R.-C., C.V.O., M.I.T., F.B., and C.S.; Resources, C.V.O., F.B., and C.S.; Writing—original draft, Á.R.-C., I.C., V.S., M.d.L.M., C.V.O., M.Á.L.-C., M.I.T., F.B., and C.S.; Writing一review \& editing, Á.R.-C., I.C., V.S., M.d.L.M., C.V.O., M.Á.L.-C., M.I.T., F.B., and C.S.

Funding: The Spanish Ministry of Economy and Competitiveness (project AGL2013-48946-C) supported this work. Acknowledgments: The Spanish Ministry of Economy and Competitiveness supported this work.

Conflicts of Interest: The authors declare no conflict of interest. None of the authors has any conflict of interest that could affect the performance of the work or the interpretation of the data.

\section{References}

1. Shewry, P.R.; Hey, S.J. The contribution of wheat to human diet and health. Food Energy Secur. 2015, 4, 178-202. [CrossRef] [PubMed]

2. Food and Agriculture Organization of the United Nations. Available online: http:/ / faostat3.fao.org (accessed on 15 October 2018).

3. Ozuna, C.V.; Barro, F. Characterization of gluten proteins and celiac disease-related immunogenic epitopes in the Triticeae: Cereal domestication and breeding contributed to decrease the content of gliadins and gluten. Mol. Breed. 2018, 38, 22. [CrossRef]

4. Feldman, M.; Levy, A.A. Genome evolution due to allopolyploidization in wheat. Genetics 2012, 192, $763-774$. [CrossRef] [PubMed]

5. López-Merino, L.; Leroy, S.A.G.; Haldorsen, S.; Heun, M.; Reynolds, A. Can Triticum urartu (Poaceae) be identified by pollen analysis? Implications for detecting the ancestor of the extinct two-grained einkorn-like wheat. Bot. J. Linn. Soc. 2015, 177, 278-289. [CrossRef] [PubMed]

6. Petersen, G.; Seberg, O.; Yde, M.; Berthelsen, K. Phylogenetic relationships of Triticum and Aegilops and evidence for the origin of the A, B, and D genomes of common wheat (Triticum aestivum). Mol. Phylogenet. Evol. 2006, 39, 70-82. [CrossRef]

7. Kasarda, D.D. Can an increase in celiac disease be attributed to an increase in the gluten content of wheat as a consequence of wheat breeding? J. Agric. Food Chem. 2013, 61, 1155-1159. [CrossRef] [PubMed]

8. Arzani, A.; Ashraf, M. Cultivated Ancient Wheats (Triticum spp.): A Potential Source of Health-Beneficial Food Products. Compr. Rev. Food Sci. Food Saf. 2017, 16, 477-488. [CrossRef]

9. Ludvigsson, J.F.; Leffler, D.A.; Bai, J.C.; Biagi, F.; Fasano, A.; Green, P.H.R.; Hadjivassiliou, M.; Kaukinen, K.; Kelly, C.P.; Leonard, J.N.; et al. The Oslo definitions for coeliac disease and related terms. Gut 2013, 62, 43-52. [CrossRef]

10. Fasano, A.; Sapone, A.; Zevallos, V.; Schuppan, D. Nonceliac gluten and wheat sensitivity. Gastroenterology 2015, 148, 1195-1204. [CrossRef] 
11. Herrera, M.J.; Hermoso, M.A.; Quera, R. An update on the pathogenesis of celiac disease. Revista Medica de Chile 2009, 137, 1617-1626.

12. Brandtzaeg, P. The changing immunological paradigm in coeliac disease. Immunol. Lett 2006, 105, 127-139. [CrossRef] [PubMed]

13. Maiuri, L.; Ciacci, C.; Ricciardelli, I.; Vacca, L.; Raia, V.; Auricchio, S.; Picard, J.; Osman, M.; Quaratino, S.; Londei, M. Association between innate response to gliadin and activation of pathogenic T cells in coeliac disease. Lancet 2003, 362, 30-37. [CrossRef]

14. Maiuri, L.; Ciacci, C.; Auricchio, S.; Brown, V.; Quaratino, S.; Londei, M. Interleukin 15 mediates epithelial changes in celiac disease. Gastroenterology 2000, 119, 996-1006. [CrossRef] [PubMed]

15. Qiao, S.W.; Bergseng, E.; Molberg, O.; Xia, J.; Fleckenstein, B.; Khosla, C.; Sollid, L.M. Antigen Presentation to Celiac Lesion-Derived T Cells of a 33-Mer Gliadin Peptide Naturally Formed by Gastrointestinal Digestion. J. Immunol 2004, 173, 1757-1762. [CrossRef] [PubMed]

16. Ráki, M.; Tollefsen, S.; Molberg, Ø.; Lundin, K.E.A.; Sollid, L.M.; Jahnsen, F.L. A Unique Dendritic Cell Subset Accumulates in the Celiac Lesion and Efficiently Activates Gluten-Reactive T Cells. Gastroenterology 2006, 131, 428-438. [CrossRef] [PubMed]

17. Tollefsen, S.; Arentz-Hansen, H.; Fleckenstein, B.; Molberg, Ø.; Ráki, M.; Kwok, W.W.; Jung, G.; Lundin, K.E.A.; Sollid, L.M. HLA-DQ2 and -DQ8 signatures of gluten T cell epitopes in celiac disease. J. Clin. Investig. 2006, 116, 2226-2236. [CrossRef] [PubMed]

18. Bernardo, D. Human intestinal dendritic cells as controllers of mucosal immunity. Rev. Esp. Enferm. Dig. 2013, 105, 279-290. [CrossRef] [PubMed]

19. Martínez-Esteso, M.J.; Nørgaard, J.; Brohée, M.; Haraszi, R.; Maquet, A.; O’Connor, G. Defining the wheat gluten peptide fingerprint via a discovery and targeted proteomics approach. J. Proteom. 2016, 147, 156-168. [CrossRef]

20. Allred, L.K.; Ritter, B.W. Recognition of gliadin and glutenin fractions in four commercial gluten assays. J. AOAC Int. 2010, 93, 190-196.

21. Shewry, P.R.; Halford, N.G. Cereal seed storage proteins: Structures, properties and role in grain utilization. J. Exp. Bot. 2002, 53, 947-958. [CrossRef]

22. Mena, M.C.; Sousa, C.; Mena, M.C.; Sousa, C. CHAPTER 16. Analytical Tools for Gluten Detection: Policies and Regulation. OmniaSci. Monogr. 2015, 527-564. [CrossRef]

23. Camarca, A.; Anderson, R.P.; Mamone, G.; Fierro, O.; Facchiano, A.; Costantini, S.; Zanzi, D.; Sidney, J.; Auricchio, S.; Sette, A.; et al. Intestinal T Cell Responses to Gluten Peptides Are Largely Heterogeneous: Implications for a Peptide-Based Therapy in Celiac Disease. J. Immunol. 2009, 182, 4158-4166. [CrossRef] [PubMed]

24. Shan, L.; Molberg, Ø.; Parrot, I.; Hausch, F.; Filiz, F.; Gray, G.M.; Sollid, L.M.; Khosla, C. Structural basis for gluten intolerance in Celiac Sprue. Science 2002, 297, 2275-2279. [CrossRef] [PubMed]

25. Molberg, Ø.; Uhlen, A.K.; Jensen, T.; Flæte, N.S.; Fleckenstein, B.; Arentz-Hansen, H.; Raki, M.; Lundin, K.E.A.; Sollid, L.M. Mapping of gluten T-cell epitopes in the bread wheat ancestors: Implications for celiac disease. Gastroenterology 2005, 128, 393-401. [CrossRef] [PubMed]

26. Sollid, L.M.; Qiao, S.W.; Anderson, R.P.; Gianfrani, C.; Koning, F. Nomenclature and listing of celiac disease relevant gluten T-cell epitopes restricted by HLA-DQ molecules. Immunogenetics 2012, 64, 455-460. [CrossRef] [PubMed]

27. Escarnot, E.; Gofflot, S.; Sinnaeve, G.; Dubois, B.; Bertin, P.; Mingeot, D. Reactivity of gluten proteins from spelt and bread wheat accessions towards A1 and G12 antibodies in the framework of celiac disease. Food Chem. 2018, 268, 522-532. [CrossRef] [PubMed]

28. Dubois, B.; Bertin, P.; Muhovski, Y.; Escarnot, E.; Mingeot, D. Development of TaqMan probes targeting the four major celiac disease epitopes found in $\alpha$-gliadin sequences of spelt (Triticum aestivum ssp. spelta) and bread wheat (Triticum aestivum ssp. aestivum). Plant Methods 2017, 13, 1-14. [CrossRef]

29. Ozuna, C.V.; Iehisa, J.C.M.; Giménez, M.J.; Alvarez, J.B.; Sousa, C.; Barro, F. Diversification of the celiac disease $\alpha$-gliadin complex in wheat: A 33-mer peptide with six overlapping epitopes, evolved following polyploidization. Plant J. 2015, 82, 794-805. [CrossRef]

30. Moron, B.; Cebolla, A.; Manyani, H.; Alvarez-Maqueda, M.; Megias, M.; Thomas, M.D.C.; Lopez, M.C.; Sousa, C. Sensitive detection of cereal fractions that are toxic to celiac disease patients by using monoclonal antibodies to a main immunogenic wheat peptide. Am. J. Clin. Nutr. 2008, 87, 405-414. [CrossRef] 
31. Morón, B.; Bethune, M.T.; Comino, I.; Manyani, H.; Ferragud, M.; López, M.C.; Cebolla, Á.; Khosla, C.; Sousa, C. Toward the assessment of food toxicity for celiac patients: Characterization of monoclonal antibodies to a main immunogenic gluten peptide. PLOS ONE 2008, 3, 1-13. [CrossRef]

32. Comino, I.; Real, A.; Vivas, S.; Síglez, M.Á.; Caminero, A.; Nistal, E.; Casqueiro, J.; Rodríguez-Herrera, A.; Cebolla, Á.; Sousa, C. Monitoring of gluten-free diet compliance in celiac patients by assessment of gliadin 33-mer equivalent epitopes in feces. Am. J. Clin. Nutr. 2012, 95, 670-677. [CrossRef] [PubMed]

33. ArentzHansen, H.; McAdam, S.N.; Molberg, Ø.; Fleckenstein, B.; Lundin, K.E.A.; Jørgensen, T.J.D.; Jung, G.; Roepstorff, P.; Sollid, L.M. Celiac lesion T cells recognize epitopes that cluster in regions of gliadins rich in proline residues. Gastroenterology 2002, 123, 803-809. [CrossRef]

34. Vader, W.; Stepniak, D.; Kooy, Y.; Mearin, L.; Thompson, A.; van Rood, J.J.; Spaenij, L.; Koning, F. The HLA-DQ2 gene dose effect in celiac disease is directly related to the magnitude and breadth of gluten-specific T cell responses. Proc. Natl. Acad. Sci. USA 2003, 100, 12390-12395. [CrossRef] [PubMed]

35. Ciccocioppo, R.; Di Sabatino, A.; Corazza, G.R. The immune recognition of gluten in coeliac disease. Clin. Exp. Immunol. 2005, 140, 408-416. [CrossRef] [PubMed]

36. Payne, P.I.; Jackson, E.A.; Holt, L.M. The association between $\gamma$-gliadin 45 and gluten strength in durum wheat varieties: A direct causal effect or the result of genetic linkage? J. Cereal Sci. 1984, 2, 73-81. [CrossRef]

37. Jouanin, A.; Gilissen, L.J.W.J.; Boyd, L.A.; Cockram, J.; Leigh, F.J.; Wallington, E.J.; van den Broeck, H.C.; van der Meer, I.M.; Schaart, J.G.; Visser, R.G.F.; et al. Food processing and breeding strategies for coeliac-safe and healthy wheat products. Food Res. Int. 2018, 110, 11-21. [CrossRef]

38. Van Herpen, T.W.J.M.; Goryunova, S.V.; van der Schoot, J.; Mitreva, M.; Salentijn, E.; Vorst, O.; Schenk, M.F.; van Veelen, P.A.; Koning, F.; van Soest, L.J.M.; et al. Alpha-gliadin genes from the A, B, and D genomes of wheat contain different sets of celiac disease epitopes. BMC Genom. 2006, 7, 1-13. [CrossRef]

39. Salentijn, E.M.; Goryunova, S.V.; Bas, N.; van der Meer, I.M.; van den Broeck, H.C.; Bastien, T.; Gilissen, L.J.W.J.; Smulders, M.J.M. Tetraploid and hexaploid wheat varieties reveal large differences in expression of alpha-gliadins from homoeologous Gli-2 loci. BMC Genom. 2009, 10, 48. [CrossRef]

40. Kim, C.Y.; Quarsten, H.; Bergseng, E.; Khosla, C.; Sollid, L.M. Structural basis for HLA-DQ2-mediated presentation of gluten epitopes in celiac disease. Proc. Natl. Acad. Sci. USA 2004, 101, 4175-4179. [CrossRef]

41. Tye-Din, J.A.; Stewart, J.A.; Dromey, J.A.; Beissbarth, T.; Van Heel, D.A.; Tatham, A.; Henderson, K.; Mannering, S.I.; Gianfrani, C.; Jewell, D.P.; et al. Comprehensive, quantitative mapping of T cell epitopes in gluten in celiac disease. Sci. Transl. Med. 2010, 2. [CrossRef]

42. Schumann, M.; Siegmund, B.; Schulzke, J.D.; Fromm, M. Celiac Disease: Role of the Epithelial Barrier. Cell. Mol. Gastroenterol. Hepatol. 2017, 3, 150-162. [CrossRef] [PubMed]

43. Vartdal, F.; Johansen, B.H.; Friede, T.; Thorpe, C.J.; Stevanović, S.; Eriksen, J.E.; Sletten, K.; Thorsby, E.; Rammensee, H.G.; Sollid, L.M. The peptide binding motif of the disease associated HLA-DQ $\left(\alpha 1\left(^{*}\right) 0501, \beta\right.$ $1\left(^{*}\right)$ 0201) molecule. Eur. J. Immunol. 1996, 26, 2764-2772. [CrossRef] [PubMed]

44. Arentz-Hansen, H.; Korner, R.; Molberg, O.; Quarsten, H.; Vader, W.; Kooy, Y.M.C.; Lundin, K.E.A.; Koning, F.; Roepstorff, P.; Sollid, L.M.; et al. The intestinal T cell response to a-gliadin in adult celiac disesae is focused on a single deamidated glutamine targeted by tissue transglutaminase. J. Exp. Med. 2000, 191, 603-612. [CrossRef]

45. Ellis, H.J.; Pollock, E.L.; Engel, W.; Fraser, J.S.; Rosen-Bronson, S.; Wieser, H.; Ciclitira, P.J. Investigation of the putative immunodominant T cell epitopes in coeliac disease. Gut 2003, 52, 212-217. [CrossRef] [PubMed]

(C) 2019 by the authors. Licensee MDPI, Basel, Switzerland. This article is an open access article distributed under the terms and conditions of the Creative Commons Attribution (CC BY) license (http://creativecommons.org/licenses/by/4.0/). 